\title{
FAKTOR-FAKTOR PSIKOLOGIS YANG MEMPENGARUHI INTENSI MEMBELI PRODUK FASHION TIRUAN
}

\author{
Jazran Efendi \\ Akhmad Baidun \\ UIN Syarif Hidayatullah Jakarta \\ jazranefendi1@yahoo.com
}

\begin{abstract}
The aim of the study was to examine psychological factors that predict intention to buy imitation fashoin product. This study used quantitative apporoach by multiple regression with significance level at 0.05. Data were collected from 150 visitors of Tanah Abang shopping center, Central Jakarta, using non-probability sampling. The result showed that there is significance effect of independent variable towards intention to buy imitation fashion product with $R^{2}$ is 0.334 . The test of minor hypotheses showed that motivation to comply has significant effect towards intention to buy imitation fashion product while behavioral beliefs, outcome evaluation, normative beliefs, control beliefs, power of factor and sex have no sginificant effect. Based on the result, consumers are suggested to explore fashion product they want to purchase so they will not get any loss while willing to purchase imitation fashion product. They are also expected to not easily following trends.
\end{abstract}

Keywords: imitation fashion product, intention to buy, psychological factors

\begin{abstract}
Abstrak
Penelitian ini dilakukan untuk mengetahui faktor-faktor psikologis yang mempengaruhi intensi membeli produk fashion tiruan. Penelitian ini menggunakan pendekatan kuantitatif dengan analisis regresi berganda dengan signifikansi 0.05. Sampel berjumlah 150 orang pengunjung kawasan pusat perbelanjaan Tanah Abang yang berlokasi di Jakarta Pusat yang diambil dengan teknik non-probability sampling. Hasil penelitian ini menunjukkan bahwa ada pengaruh yang signifikan dari seluruh independent variable yang diteliti terhadap intensi membeli produk fashion tiruan sebagai dependent variable dengan nilai $R$ Square sebesar 0.334 atau 33.4\%. Hasil uji hipotesis minor yang menguji dari ketujuh variabel menunjukkan variabel motivation to comply berpengaruh secara signifikan terhadap intensi membeli produk fashion tiruan, sedangkan behavioral beliefs, outcome evaluation, normative beliefs, control beliefs, power of factor dan jenis kelamin tidak menunjukkan pengaruh yang signifikan terhadap intensi membeli produk fashion tiruan. Berdasarkan hasil penelitian, konsumen disarankan untuk lebih menggali produk fashion yang akan dibeli agar tidak mendapatkan kerugian apabila hendak membeli produk fashion tiruan dan diharapkan tidak mudah mengikuti pendapat orang lain (latah) atau mudah begitu saja mengikuti tren fashion.
\end{abstract}

Kata kunci: faktor-faktor psikologis, intensi membeli, produk fashion tiruan 


\section{PENDAHULUAN}

Pakaian atau busana sudah menjadi kebutuhan pokok manusia selain makanan dan tempat tinggal. Manusia membutuhkan pakaian untuk melindungi tubuh dari bagian yang tidak terlihat dan menutupi dirinya, juga meningkatkan kenyamanan, keamanan dari terbakar sinar matahari atau berbagai fungsi lainnya. Pakaian pada mulanya dibuat dari tanah liat, daun-daunan, kulit binatang dan kulit kayu (Judy, 1986).

Perkembangan model dan jenis pakaian mengacu pada adat-istiadat, kebiasaan, dan budaya masyarakat tertentu atau yang lebih dikenal dengan istilah fashion. Fashion merupakan cara berpakaian sehari-hari untuk suatu kurun waktu tertentu, yang diterima dan diikuti oleh sebagian masyarakat. Fashion terus berubah dari waktu ke waktu, seringkali jauh lebih cepat daripada budaya dimana fashion itu berkembang. Kata fashionable dipakai untuk menggambarkan seseorang atau sesuatu yang cocok dengan look yang populer pada suatu masa, kebalikannya disebut unfashionable (Kamus Mode, 2010).

Produk fashion pun kini dengan mudah ditemukan di pusat perbelanjaan atau mal dengan berbagai model dan merek, tentu saja akan memudahkan konsumen dalam mencari produk fashion yang diinginkan. Kegiatan berbelanja memang sudah tidak bisa lepas dalam kehidupan sehari-hari terutama masyarakat perkotaan khususnya ibukota Jakarta. Kota Jakarta telah tumbuh menjadi sebuah kawasan komersial yang tanpa diduga ternyata menyimpan jumlah mal terbanyak di dunia. Sebanyak 130 mal yang tersebar di seluruh kota Jakarta menjadikan para perusahaan pemegang lisensi produk internasional dengan mudah mempengaruhi konsumen dengan merek kenamaan dunia. Sebut saja PT. Mugi Rekso Abadi, PT. Bagasi Luks, Time International ataupun Mahagaya Perdana yang telah sukses membangun mal di Jakarta menjadi tak kalah bersaing dengan mal kelas dunia (Amalludin, dalam Putri, 2010).

Penggunaan produk bermerek kelas dunia tidak hanya diperuntukkan bagi konsumen yang berasal dari status sosial kalangan atas. Konsumen yang berasal dari status sosial kalangan menengah pun ingin menyandang penggunaan produk fashion ini, tentunya menciptakan efek yang beragam. Ketika pakaian ternyata menyandang merek desainer terkenal, hal itu dapat dianggap sebagai kemewahan untuk mengekspresikan diri tentang ide dan arti diri seseorang (Mowen, 2002). Dengan demikian konsumen termotivasi dan berkeinginan untuk memberikan citra diri kepada orang lain dengan 
kemampuan untuk membayar harga tinggi untuk produk bermerek tertentu (Solomon, dalam Rajagopal, 2010).

Sebagai konsumen yang menghargai karya orang lain atau hak cipta. Konsumen seharusnya membeli produk fashion asli, tetapi tidak sedikit konsumen yang memilih bahkan menggemari produk fashion tiruan. Kecenderungan perilaku konsumen di Indonesia dalam membeli produk fashion ternyata lebih menggemari produk fashion tiruan dibandingkan dengan produk fashion asli. Hasil survei membuktikan dari 34 konsumen yang diwawancarai, 20 orang $(58.82 \%)$ ternyata memiliki kecenderungan untuk membeli produk fashion tiruan, 13 orang (38.24\%) memiliki kecenderungan untuk membeli produk fashion asli dan satu orang (2.94\%) memilih lain-lain (www.forum.kompas.com, diakses pada tanggal 7 November 2013 pada pukul 20.00 WIB). Menurut Cordell (dalam Siham, 1996), konsumen lebih memilih produk fashion tiruan dikarenakan karena status simbolik dari merek yang tertera, lokasi berbelanja yang mudah diakses, dan rentang harga yang lebih murah dibandingkan dengan produk fashion asli.

Fenomena pemalsuan produk yang sedang berkembang menyebabkan masalah sosial dan ekonomi yang sangat serius dan dapat menimbulkan gejala ekonomi dan kepercayaan konsumen terhadap produk bermerek tertentu (Tom, et al., dalam Ahmad, 2012). Pembajakan atau pemalsuan dapat dikatakan sebagai akibat dari meningkatnya perdagangan global dan, majunya perkembangan teknologi, dan meningkatnya barang yang dianggap bernilai untuk dipalsukan (Business News, dalam Boonghee, 2005). Merek barang mewah mudah dipalsukan karena barang tersebut mudah untuk dijual dan tidak menciptakan biaya produksi yang tinggi (Ervina, 2013).

Banyak peneliti berpendapat bahwa meningkatnya pasar global akan mengurangi homogenitas perilaku konsumen dalam suatu negara dan mampu meningkatkan kesamaan di seluruh Negara (Rajagopal, 2010). Pemalsuan sulit untuk dihentikan karena banyaknya permintaan dari konsumen di seluruh dunia (Bloch, et al., dalam Ahmad, 2012). Pemalsuan merek populer merupakan masalah yang serius di dunia tanpa terkecuali di Indonesia. Industri fashion khususnya, produk palsu dapat ditemukan di sejumlah produk barang seperti pakaian, sepatu, jam tangan dan perhiasan (Yoo \& Lee, 2009). Sebuah laporan menyebutkan bahwa investor internasional ragu untuk melakukan investasi industri pakaian di Indonesia karena level pemalsuan yang tinggi di pasaran (Ekawati, dalam Ervina, 
2013). Kerugian akibat pemalsuan produk fashion yang terjadi di Indonesia pada tahun 2002 sebesar Rp. 2 Trilyun dan 9 tahun kemudian tepatnya pada tahun 2011 sebesar Rp. 43.2 Trilyun (www.thejakartapost.com, dalam Ervina, 2013)

Berdasarkan uraian paragraf di atas, kerugian yang dialami sektor industri di Indonesia terus meningkat setiap tahunnya. Kecenderungan konsumen memilih produk fashion tiruan memicu pertumbuhan pasar gelap yang merugikan berbagai pihak. Fenomena seperti ini mendorong penelitian mengenai perilaku konsumen dalam membeli produk fashion tiruan sangat dibutuhkan (Han, 2007).Konsumen akhirnya menilai, mencari, membeli, dan memakai produk yang dibutuhkan. Penjelasan tersebut dapat dikatakan bahwa untuk mewujudkan suatu aktivitas membeli perlu adanya kemauan yang kuat untuk melakukannya (Engel, 2006).

Menurut Ajzen (2005) kemauan yang kuat untuk melakukan suatu tingkah laku, termasuk tingkah laku membeli, dapat dijelaskan melalui konsep intensi. Intensi dalam diri seseorang menggambarkan aspek internal maupun eksternal yang mempengaruhi orang tersebut dalam mewujudkan suatu perilaku. Faktor yang mempengaruhi intensi menurut Ajzen (2005) yaitu sikap, norma subjektif dan perceived behavioral control. Sikap diasumsikan pada derajat seseorang dari evaluasi yang disukai atau tidak disukai pada perilaku tertentu (Ajzen, 2012). Sikap ditentukan oleh dua determinan yaitu behavioral beliefs dan outcome evaluation (Ajzen, 2005). Sebelum seseorang memunculkan perilaku membeli produk fashion tiruan, seseorang diasumsikan memiliki intensi dari beberapa beliefs atau keyakinan untuk menampilkan perilaku tersebut. Keyakinan positif dalam membeli produk fashion tiruan seperti harga yang lebih murah mampu menjadi nilai kompensasi tersendiri bagi konsumen terlepas dari kualitas produk yang lebih inferior. Konsumen pun memiliki sikap positif dalam membeli produk fashion tiruan, begitu juga sebaliknya beliefs negatif juga akan mempengaruhi sikap konsumen menjadi negatif terhadap produk fashion tiruan.

Norma subjektif merupakan persepsi orang lain (significant other) yang dianggap penting bagi seseorang (Ajzen, 2005). Norma subjektif dipengaruhi oleh normative beliefs dan motivation to comply. Keyakinan seseorang dalam membeli produk fashion tiruan juga dipengaruhi oleh orang lain (significant other). Seseorang yang ingin mengikuti tren fashion seperti busana yang dikenakan oleh artis idolanya atau kostum klub sepakbola yang digemari, maka seseorang akan memiliki intensi untuk membeli 
produk fashion tiruan seperti jersey tiruan yang dikenakan pula oleh teman sebayanya.

Perceived behavioral control (PBC), merupakan keyakinan seseorang akan adanya faktor yang mendukung atau menghambat munculnya suatu perilaku (Ajzen, 2005). Perceived behavioral control (PBC) dipengaruhi oleh dua determinan yaitu control beliefs dan power of factor. Intensi yang dimiliki seseorang untuk membeli produk fashion tiruan ternyata memiliki faktor yang mendukung seperti lokasi yang berdekatan dengan tempat tinggal dan pendapatan yang minim sehingga tak mampu membeli produk fashion asli yang harganya jauh lebih mahal. Faktor penghambat konsumen dalam membeli produk fashion tiruan seperti teman sebaya yang memang memiliki sikap negatif terhadap produk fashion tiruan, informasi yang kurang memadai mengenai produk fashion tiruan dan sebagainya.

Ajzen, Joyce, Sheikh, dan Cote (2011) melakukan penelitian tentang memprediksi perilaku melalui peran akurasi informasi dengan melakukan empat penelitian tentang intensi, yaitu intensi hemat energi, intensi mengkonsumsi minuman alkohol, intensi beribadah di masjid, dan intensi voting untuk mendukung aktivitas mahasiswa muslim. Hasil keempat penelitian tersebut diketahui bahwa sikap, norma subjektif dan perceived behavioral control memberikan pengaruh yang signifikan terhadap intensi. Hasil penelitian pertama, sikap, norma subjketif dan perceived behavioral control memberikan pengaruh yang signifikan sebesar $69 \%$ terhadap intensi hemat energi. Hasil penelitian kedua, intensi untuk mengkonsumsi minuman alkohol diprediksi dengan tingkat akurasi yang tinggi, yaitu sebesar $87 \%$. Hasil penelitian ketiga pun menunjukkan kotribusi sikap, norma subjektif dan perceived behavioral control terhadap intensi beribadah di masjid sebesar 46\%. Dan hasil penelitian yang keempat mengenai intensi voting untuk mendukung aktivitas mahasiswa muslim yaitu sebesar $69 \%$.

Pengaruh jenis kelamin terhadap intensi membeli pernah diteliti oleh Jason M. Carpenter (2011) dalam jurnal penelitiannya berjudul Consumer Attitudes toward Counterfeit Fashion Product: Does Gender Matter?. Hasil dari penelitian ini dapat disimpulkan adanya pengaruh yang signifikan antara faktor jenis kelamin terhadap keyakinan mengenai pandangan atau keyakinan dalam membeli produk fashion tiruan. Studi ini juga menjelaskan bahwa perempuan membutuhkan dorongan insentif finansial lebih besar dari pria untuk memesan atau melakukan transaksi jual-beli di pasar gelap (black market). 


\section{METODE}

Populasi pada penelitian ini yaitu pengunjung kawasan pusat perbelanjaan Tanah Abang yang berlokasi di Jakarta Pusat. Alasan peneliti memilih kawasan pusat perbelanjaan Tanah Abang sebagai tempat penelitian karena mampu menggambarkan arah tendensi pengunjung untuk berintensi membeli produk fashion asli atau tiruan dan merupakan kawasan berbelanja terbesar di Indonesia. Populasi dalam penelitian ini memiliki kriteria sebagai berikut:

1. Pengunjung kawasan pusat perbelanjaan Tanah Abang

2. Berusia diatas 17 tahun

3. Bersedia mengisi kuesioner penelitian.

Adapun jumlah sampel yang diambil sebanyak 150 orang. Instrumen pengumpulan data yang digunakan dalam penelitian ini berbentuk kuesioner dengan menggunakan skala model Likert yang telah diadaptasi dan dimodifikasi menjadi empat alternatif pilihan jawaban yakni, sangat setuju, setuju, tidak setuju dan sangat tidak setuju. Terdapat empat skala instrumen pengumpulan data yang digunakan, yaitu skala intensi membeli, sikap, norma subjektif, dan perceived behavioral control.

1. Alat ukur intensi membeli

Alat ukur intensi membeli merupakan sebuah skala yang digunakan untuk mengukur variabel intensi membeli. Peneliti menggunakan sepuluh item untuk mengukur variabel intensi membeli yang diperoleh dengan melakukan adaptasi dan modifikasi alat ukur dari Cheng, Fu, dan Tu dengan menambahkan tujuh item yang telah disesuaikan dengan teori planned behavior (Ajzen, 2005). Setelah dilakukan uji validitas konstruk dengan menggunakan Confirmatory Factor Analysis (CFA) diperoleh model fit dengan Chi-Square $=32.06, \mathrm{df}=24, \mathrm{P}-\mathrm{value}=0.12562, \mathrm{RMSEA}=0.047$. Dari 10 item yang diuji terdapat 3 item yang nilai t-nya di bawah 1.96 sehingga hanya 7 item yang diikutsertakan dalam perhitungan skor faktor.

2. Alat ukur sikap

Alat ukur sikap merupakan sebuah skala yang digunakan untuk mengukur variabel sikap. Peneliti melakukan adaptasi dan modifikasi alat ukur sikap dari Cheng, Fu, dan Tu (2011) dengan melakukan penambahan sebanyak 12 item, sehingga jumlah keseluruhan sebanyak 20 item. 
(1) Setelah dilakukan uji validitas konstruk dengan menggunakan Confirmatory Factor Analysis (CFA) pada dimensi behavioral beliefs diperoleh model fit dengan Chi-Square $=39.42, \mathrm{df}=27, \mathrm{P}$-value $=$ 0.05801 , RMSEA $=0.056$. Dari 10 item yang diuji tidak terdapat item yang nilai t-nya di bawah 1.96 sehingga secara keseluruhan item tersebut dapat diikutsertakan dalam perhitungan skor faktor.

( Setelah dilakukan uji validitas konstruk dengan menggunakan Confirmatory Factor Analysis (CFA) pada dimensi outcome evaluation diperoleh model fit dengan Chi-Square $=37.33, \mathrm{df}=25, \mathrm{P}$-value $=$ 0.05366 , RMSEA $=0.058$. Dari 10 item yang diuji terdapat satu item yang nilai t-nya di bawah 1.96 sehingga hanya sebanyak 9 item yang dapat dikutsertakan dalam perhitungan skor faktor.

3. Alat ukur norma subjektif

Alat ukur norma subjektif merupakan sebuah skala yang digunakan untuk mengukur variabel norma subjektif. Peneliti melakukan adaptasi dan modifikasi alat ukur skala Subjective Norm (SN) berdasarkan konstruk pengukuran Ajzen (1991), dengan menambahkan 6 item, sehingga jumlah menjadi 8 item.

( Setelah dilakukan uji validitas konstruk dengan menggunakan Confirmatory Factor Analysis (CFA) pada dimensi normative beliefs diperoleh model fit dengan Chi-Square $=0.09, \mathrm{df}=2, \mathrm{P}$-value $=0.00021$, RMSEA $=0.000$. Dari empat item yang diuji tidak terdapat item yang nilai t-nya dibawah 1.96 sehingga secara keseluruhan item tersebut dapat diikutsertakan dalam perhitungan skor faktor.

( ) Setelah dilakukan uji validitas konstruk dengan menggunakan Confirmatory Factor Analysis (CFA) pada dimensi motivation to comply diperoleh model fit dengan Chi-Square $=0.07, \mathrm{df}=1, \mathrm{P}$-value $=$ 0.79735 , RMSEA $=0.000$. Dari empat item yang diuji tidak terdapat item yang nilai t-nya dibawah 1.96 sehingga secara keseluruhan item tersebut dapat diikutsertakan dalam perhitungan skor faktor.

4. Alat ukur perceived behavioral control

Alat ukur perceived behavioral control merupakan sebuah skala yang digunakan untuk mengukur variabel perceived behavioral control. Peneliti melakukan adaptasi dan modifikasi alat ukur dari Cheng, $\mathrm{Fu}$, dan $\mathrm{Tu}$ (2011), dengan menambahkan 19 item, sehingga jumlah menjadi 22 item.

( Setelah dilakukan uji validitas konstruk dengan menggunakan Confirmatory Factor Analysis (CFA) pada dimensi control beliefs 
diperoleh model fit dengan Chi-Square $=36.74, \mathrm{df}=26, \mathrm{P}$-value $=$ 0.07889 , RMSEA $=0.053$. Dari 11 item yang diuji terdapat satu item yang nilai t-nya dibawah 1.96 sehingga hanya sebanyak 10 item saja yang diikutsertakan dala perhitungan skor faktor.

( Setelah dilakukan uji validitas konstruk dengan menggunakan Confirmatory Factor Analysis (CFA) pada dimensi power of factor diperoleh model fit dengan Chi-Square $=40.79, \mathrm{df}=31, \mathrm{P}$-value $=$ 0.11216 , RMSEA $=0.045$. Dari 11 item yang diuji terdapat dua item yang nilai t-nya dibawah 1.96 sehingga hanya sebanyak 9 item yang dapat diikutsertakan dalam perhitungan skor faktor.

\section{Teknik Analisis Data}

Untuk melihat pengaruh independent variable yang diteliti yaitu behavioral beliefs, outcome evaluation, normative beliefs, motivation to comply, control beliefs, power of factor dan jenis kelamin terhadap dependent variable yaitu intensi membeli, peneliti menggunakan teknik statistik analisis regresi berganda (multiple regression analysis).

\section{HASIL}

Subjek penelitian berdasarkan jenis kelamin yaitu laki-laki sebanyak 70 orang (46.6\%) dan perempuan sebanyak 80 orang (53.4\%). Selanjutnya berdasarkan usia, dapat diketahui bahwa subjek penelitian berdasarkan jumlah usia terbanyak yaitu $<20$ tahun sebanyak 43 orang (28.6\%), usia 20-30 tahun sebanyak 96 orang $(64 \%)$ dan usia $>30$ orang sebanyak 11 orang $(7.4 \%)$. Kemudian berdasarkan intensitas bepergian ke pusat perbelanjaan (mal) diketahui bahwa subjek penelitian yang datang setiap hari sebanyak 4 orang (2.7\%), seminggu sekali sebanyak 24 orang (16\%), sebulan sekali sebanyak 47 orang $(31.3 \%)$ dan enam bulan sekali sebanyak 27 orang (18\%).

\section{Hasil Uji}

Langkah pertama peneliti melihat besaran $\mathrm{R}$ square untuk mengetahui berapa persen (\%) varians DV yang dijelaskan oleh IV seperti yang dijelaskan tabel 1.0 di bawah ini. 
Tabel 1

Model Summary $R$

\begin{tabular}{ccccc}
\hline Model & R & R Square & $\begin{array}{c}\text { Adjusted R } \\
\text { Square }\end{array}$ & $\begin{array}{c}\text { Std. Error of } \\
\text { the Estimate }\end{array}$ \\
\hline 1 & $.577^{\mathrm{a}}$ & .334 & .300 & 7.42839 \\
\hline
\end{tabular}

Dari tabel 1 di atas dapat dilihat bahwa perolehan R square sebesar 0.334 atau $33.4 \%$. Artinya proporsi varians dari intensi membeli yang dijelaskan oleh semua independent variable sebesar 33.4\%, sementara $66.6 \%$ sisanya dipengaruhi oleh variabel lain di luar penelitian ini. Langkah kedua peneliti menganalisis dampak dari seluruh independent variable terhadap intensi membeli. Adapun hasil uji F dapat dilihat pada tabel 2.0 di bawah ini.

Tabel 2

Anova seluruh IV Terhadap DV

\begin{tabular}{lllllll}
\hline Model & & $\begin{array}{l}\text { Sum } \\
\text { Squares }\end{array}$ & of df & $\begin{array}{l}\text { Mean } \\
\text { Square }\end{array}$ & F & Sig. \\
\hline 1 & Regression & 3914.916 & 7 & 559.274 & 10.13 & $.000^{\text {a }}$ \\
& Residual & 7835.701 & 142 & 55.181 & 5 & \\
& Total & 11750.618 & 149 & & & \\
\hline
\end{tabular}

Jika melihat kolom ke 6 dari kiri (Sig.) diketahui bahwa $(\mathrm{p}<0.05)$, maka hipotesis alternatif yang berbunyi: - Terdapat pengaruh yang signifikan behavioral beliefs, outcome evaluation, normative beliefs, motivation to comply, control beliefs, power of factor dan jenis kelamin terhadap intensi membeli produk fashion tiruan\| diterima. Artinya, ada pengaruh yang signifikan dari behavioral beliefs, outcome evaluation, normative beliefs, motivation to comply, control beliefs, power of factor dan jenis kelamin terhadap intensi membeli produk fashion tiruan.

Langkah ketiga, setelah diketahui bahwa hipotesis alternatif diterima. Selanjutnya melihat signifikan atau tidaknya koefisien regresi dari masingmasing independent variable seperti hasil koefisien regresi yang tertera pada tabel 3 . 
Tabel 3

Koefisien Regresi

\begin{tabular}{llccccc}
\hline \multirow{2}{*}{ No } & \multicolumn{1}{c}{ Model } & \multicolumn{2}{c}{$\begin{array}{c}\text { Unstandardized } \\
\text { Coefficients }\end{array}$} & $\begin{array}{c}\text { Standardized } \\
\text { Coefficients }\end{array}$ & \multirow{2}{*}{ t } & \multirow{2}{*}{ Sig. } \\
\cline { 3 - 5 } & & $\mathbf{B}$ & Std. Error & Beta & & \\
\hline 1. & (Constant) & 20.137 & 5.554 & & 3.626 & .000 \\
2. & Behavioral beliefs & .041 & .094 & .042 & .436 & .663 \\
3. & Outcome evaluation & .017 & .097 & .017 & .171 & .864 \\
4. & Normative beliefs & -.542 & .328 & -.496 & - & .101 \\
& & & & & 1.651 & \\
5. & Motivation to comply & 1.143 & .330 & 1.039 & 3.466 & .001 \\
6. & Control beliefs & -.081 & .097 & -.084 & -.836 & .405 \\
7. & Power of factor & .016 & .107 & .016 & .148 & .882 \\
8. & Jenis kelamin & .415 & 1.250 & .023 & .332 & .742 \\
\hline
\end{tabular}

Berdasarkan tabel 3 persamaan regresi penelitian ini dirumuskan sebagai berikut $(*=$ signifikan $)$.

Intensi membeli

$$
\begin{aligned}
& =20.137+0.041 \text { behavioral beliefs }+0.017 \text { outcome } \\
& \text { evaluation }-0.542 \text { normative beliefs }+1.143 \text { motivation to } \\
& \text { comply* }-0.081 \text { control beliefs }+0.016 \text { power of factor }+ \\
& 0.415 \text { jenis kelamin. }
\end{aligned}
$$

Berdasarkan tabel 3 maka hipotesis minor $\left(\mathrm{H}_{4}\right)$ yang berbunyi: -Terdapat pengaruh yang signifikan motivation to comply terhadap intensi membeli produk fashion tiruan\| diterima. Dengan demikian variabel motivation to comply secara positif memberikan pengaruh yang signifikan terhadap intensi membeli produk fashion tiruan. Variabel lainnya menghasilkan koefisien regresi yang tidak signifikan. Penjelasan dari nilai koefisien regresi yang diperoleh masing-masing independent variable adalah sebagai berikut di bawah ini.

1. Hipotesis minor $\left(\mathrm{H}_{1}\right)$ yang berbunyi - Terdapat pengaruh yang signifikan behavioral beliefs dengan intensi membeli produk fashion tiruan\| ditolak. Variabel behavioral beliefs memiliki nilai koefisien regresi sebesar 0.041 dengan signifikansi 0.663 ( $\mathrm{p}>0.05)$, yang berarti bahwa variabel behavioral beliefs tidak memberikan pengaruh yang signifikan terhadap intensi membeli produk fashion tiruan.

2. Hipotesis minor $\left(\mathrm{H}_{2}\right)$ yang berbunyi: - Terdapat pengaruh yang signifikan outcome evaluation dengan intensi membeli produk fashion tiruan \| ditolak. Variabel outcome evaluation memiliki nilai koefisien 
regresi sebesar 0.017 dengan signifikansi $0.864(\mathrm{p}>0.05)$, yang berarti bahwa variabel outcome evaluation tidak memberikan pengaruh yang signifikan terhadap intensi membeli produk fashion tiruan.

3. Hipotesis minor $\left(\mathrm{H}_{3}\right)$ yang berbunyi: -Terdapat pengaruh yang signifikan normative beliefs dengan intensi membeli produk fashion tiruan\| ditolak. Variabel normative beliefs memiliki nilai koefisien regresi sebesar -0.542 dengan signifikansi $0.101(\mathrm{p}>0.05)$, yang berarti bahwa variabel normative beliefs tidak memberikan pengaruh yang signifikan terhadap intensi membeli produk fashion tiruan.

4. Hipotesis minor $\left(\mathrm{H}_{4}\right)$ yang berbunyi: -Terdapat pengaruh yang signifikan motivation to comply dengan intensi membeli produk fashion tiruan\| diterima. Variabel motivation to comply memiliki nilai koefisien regresi sebesar 1.143 dengan signifikansi $0.001 \quad(p<0.05)$, yang berarti bahwa variabel motivation to comply memberikan pengaruh yang signifikan dengan arah koefisien positif terhadap intensi membeli produk fashion tiruan.

5. Hipotesis minor $\left(\mathrm{H}_{5}\right)$ yang berbunyi: - Terdapat pengaruh yang signifikan control beliefs dengan intensi membeli produk fashion tiruan\| ditolak. Variabel control beliefs memiliki nilai koefisien regresi sebesar 0.081 dengan signifikansi 0.405 ( $p>0.05)$, yang berarti bahwa variabel control beliefs tidak memberikan pengaruh yang signifikan terhadap intensi membeli produk fashion tiruan.

6. Hipotesis minor $\left(\mathrm{H}_{6}\right)$ yang berbunyi: -Terdapat pengaruh yang signifikan power of factor terhadap intensi membeli produk fashion tiruan\| ditolak. Variabel power of factor memiliki nilai koefisien regresi sebesar 0.016 dengan signifikansi sebesar $0.882(\mathrm{p}>0.05)$, yang berarti bahwa variabel peower of factor tidak memberikan pengaruh yang signifikan terhadap intensi membeli produk fashion tiruan.

7. Hipotesis minor $\left(\mathrm{H}_{7}\right)$ yang berbunyi: - Terdapat pengaruh yang signifikan jenis kelamin terhadap intensi membeli produk fashion tiruan\| ditolak. Variabel jenis kelamin memiliki nilai koefisien regresi sebesar 0.415 dengan signifikansi sebesar 0.740 ( $p>0.05)$, yang berarti bahwa variabel jenis kelamin tidak memberikan pengaruh yang signifikan terhadap intensi membeli produk fashion tiruan.

Kemudian langkah selanjutnya peneliti menguji penambahan proporsi varians dari tiap variabel independen jika IV tersebut dimasukkan 
satu per satu ke dalam analisis regresi. Besarnya proporsi varians pada ketangguhan mental dapat dilihat pada tabel 4 berikut:

\section{Tabel 4}

Kontribusi Varians Independent Variable Terhadap Dependent Variable

\begin{tabular}{|c|c|c|c|c|c|c|c|c|c|}
\hline \multirow[b]{2}{*}{ Model } & \multirow[b]{2}{*}{$\mathbf{R}$} & \multirow[b]{2}{*}{$\begin{array}{c}\text { R } \\
\text { Square }\end{array}$} & \multirow[b]{2}{*}{$\begin{array}{l}\text { Adjusted } \\
\text { R Square }\end{array}$} & \multirow{2}{*}{$\begin{array}{c}\text { Std. } \\
\text { Error of } \\
\text { the } \\
\text { Estimate }\end{array}$} & \multicolumn{5}{|c|}{ Change Statistics } \\
\hline & & & & & $\begin{array}{c}\text { R } \\
\text { Square } \\
\text { Change }\end{array}$ & $\begin{array}{c}\text { F } \\
\text { Change }\end{array}$ & $\begin{array}{c}\text { df } \\
1\end{array}$ & df 2 & $\begin{array}{c}\text { Sig F } \\
\text { Change }\end{array}$ \\
\hline 1 & $.004^{\mathrm{a}}$ & .000 & -.007 & 8.91037 & .000 & .002 & 1 & 148 & .961 \\
\hline 2 & $.044^{\mathrm{b}}$ & .002 & -.012 & 8.93208 & .002 & .281 & 1 & 147 & .597 \\
\hline 3 & $.521^{\mathrm{c}}$ & .272 & .257 & 7.65520 & .270 & 54.129 & 1 & 146 & .000 \\
\hline 4 & $.573^{\mathrm{d}}$ & .329 & .310 & 7.37718 & .057 & 12.212 & 1 & 145 & .001 \\
\hline 5 & $.577^{\mathrm{e}}$ & .333 & .309 & 7.38024 & .004 & .880 & 1 & 144 & .350 \\
\hline 6 & $.577^{\mathrm{f}}$ & .333 & .305 & 7.40525 & .000 & .029 & 1 & 143 & .865 \\
\hline 7 & $.577^{\mathrm{g}}$ & .334 & .300 & 7.42839 & .001 & .110 & 1 & 142 & .740 \\
\hline
\end{tabular}

a. Predictors: (Constant), Behavioral_beliefs

b. Predictors: (Constant), Behavioral_beliefs, Outcome_evaluation

c. Predictors: (Constant), Behavioral_beliefs, Outcome_evaluation, Normative_beliefs

d. Predictors: (Constant), Behavioral_beliefs, Outcome_evaluation, Normative_beliefs, Motivation_to_comply

e.Predictors: (Constant), Behavioral_beliefs, Outcome_evaluation, Normative_beliefs, Motivation_to_comply, Control_beliefs

f.Predictors: (Constant), Behavioral_beliefs, Outcome_evaluation, Normative_beliefs, Motivation_to_comply, Control_beliefs, Powerof_factor

g. Predictors: (Constant), Behavioral_beliefs, Outcome_evaluation, Normative_beliefs, Motivation_to_comply, Control_beliefs, Powerof_factor, Jenis_kelamin

Berdasarkan data yang ditampilkan pada tabel 4 dapat dijelaskan bahwa:

1. Variabel behavioral beliefs memberikan sumbangan sebesar 0.000 atau $0 \%$ terhadap varians intensi membeli produk fashion tiruan. Sumbangan tersebut tidak signifikan dengan nilai $\mathrm{F}=0.002$, $\mathrm{df} 1=1$, dan $\mathrm{df} 2=148$.

2. Variabel outcome evaluation memberikan sumbangan sebesar 0.002 atau $0.2 \%$ terhadap varians intensi membeli produk fashion tiruan. Sumbangan tersebut tidak signifikan dengan nilai $\mathrm{F}=0.281$ dan $\mathrm{df} 1=1$, dan $\mathrm{df} 2=147$.

3. Variabel normative beliefs memberikan sumbangan sebesar 0.270 atau $27 \%$ terhadap varians intensi membeli produk fashion tiruan. Sumbangan tersebut signifikan dengan nilai $\mathrm{F}=54.129, \mathrm{df} 1=1$, dan $\mathrm{df} 2=146$.

4. Variabel motivation to comply memberikan sumbangan sebesar 0.057 atau $5.7 \%$ terhadap varians intensi membeli produk fashion tiruan. 
Sumbangan tersebut signifikan dengan nilai $\mathrm{F}=12.212$, $\mathrm{df} 1=1$, dan $\mathrm{df} 2=$ 145.

5. Variabel control beliefs memberikan sumbangan sebesar 0.004 atau $0.4 \%$ terhadap varians intensi membeli produk fashion tiruan. Sumbangan tersebut tidak signifikan dengan nilai $\mathrm{F}=0.880, \mathrm{df} 1=1$, dan $\mathrm{df} 2=144$.

6. Variabel power of factor memberikan sumbangan sebesar 0.000 atau $0 \%$ terhadap varians intensi membeli produk fashion tiruan. Sumbangan tersebut tidak signifikan dengan nilai $\mathrm{F}=0.029 \mathrm{df} 1=1$, dan $\mathrm{df} 2=143$.

7. Variabel jenis kelamin memberikan sumbangan sebesar 0.001 atau $0.1 \%$ terhadap varians intensi membeli produk fashion tiruan. Sumbangan tersebut tidak signifikan dengan nilai $\mathrm{F}=0.110, \mathrm{df} 1=1$, dan $\mathrm{df} 2=142$.

Dengan demikian dapat disimpulkan bahwa seluruh independent variable, hanya dua IV yang memberikan sumbangan signifikan terhadap DV yaitu normative beliefs dan motivation to comply. Sementara lima variabel yang lain memberikan sumbangan tidak signifikan. Dari keseluruhan independent variable tersebut dapat dilihat variabel yang paling besar memberikan sumbangan terhadap intensi membeli produk fashion tiruan. Hal tersebut dapat diketahui dengan melihat $\mathrm{R}^{2}$ change, semakin besar maka semakin banyak sumbangan yang diberikan terhadap dependent variable. Dari tabel 4.0 di atas dapat diketahui bahwa keseluruhan independent variable yang secara signifikan memberikan sumbangan dari yang terkecil sampai terbesar berdasarkan nilai proporsi varians yaitu motivation to comply dengan $\mathrm{R}^{2}$ change sebesar 0.057 atau $5.7 \%$, dan yang terbesar normative beliefs dengan $\mathrm{R}^{2}$ change sebesar 0.270 atau $27 \%$.

Dengan demikian dapat disimpulkan bahwa terdapat pengaruh intensi membeli yang dijelaskan oleh seluruh independent variable yaitu behavioral beliefs, outcome evaluation, normative beliefs, motivation to comply, control beliefs, power of factor dan jenis kelamin dengan R Square sebesar 0.334 atau $33.4 \%$. Berdasarkan hasil uji t dari ke 7 independent variable yang diteliti, terdapat satu variabel yang signifikan yaitu motivation to comply. 


\section{DISKUSI}

Produk fashion tiruan dewasa ini mudah sekali ditemukan di pusat perbelanjaan atau pun toko di pinggir jalan, bahkan ada juga yang dapat dibeli secara online. Hal ini dapat menjadi indikasi bahwa tidak sedikit konsumen yang menggemari produk fashion tiruan. Jenis produk yang digemari konsumen pun beragam mulai dari baju, celana, sepatu, aksesoris, jam tangan dan sebagainya. Penelitian ini dilakukan dengan tujuan untuk mengetahui faktor-faktor yang mempengaruhi konsumen dalam membeli produk fashion tiruan dari sudut pandang psikologis dan demografi sehingga dapat menguak permasalahan pembajakan khususnya produk fashion. Hasil penelitian ini menunjukkan bahwa secara keseluruhan sikap, norma subjektif, perceived behavioral control dan jenis kelamin secara signifikan berpengaruh terhadap intensi membeli produk fashion tiruan dengan kontribusi R Square sebesar 0.334 atau 33.4\%.

Variabel normative beliefs memberikan pengaruh sebesar $27 \%$ dan secara negatif mempengaruhi intensi membeli produk fashion tiruan dengan kriteria tidak signifikan. Hal ini berarti tidak ada pengaruh yang signifikan dari normative belief terhadap intensi membeli produk fashion tiruan. Hasil penelitian ini tidak mendukung penelitian sebelumnya yang dilakukan oleh Davis et al (2002), bahwa normative beliefs berpengaruh secara signifikan dalam mewujudkan suatu perilaku. Berbeda dengan variabel normative beliefs, variabel motivation to comply memberikan pengaruh sebesar $5.7 \%$ dan secara positif mempengaruhi intensi membeli produk fashion tiruan dengan kriteria signifikan. Hal ini berarti semakin tinggi motivation to comply seseorang terhadap intensi membeli produk fashion tiruan maka semakin tinggi pula intensi membeli produk fashion tiruan. Hasil penelitian ini mendukung penelitian sebelumnya yang dilakukan oleh Davis et al (2002), bahwa motivation to comply berpengaruh secara signifikan dalam mewujudkan suatu perilaku. Dengan kata lain, konsumen memiliki motivasi yang tinggi ketika membeli produk fashion tiruan karena mengikuti pendapat orang lain (significant other) seperti anggota keluarga, teman, tokoh idola, atau hanya sekedar mengikuti tren fashion pada waktu tertentu.

Pada variabel control beliefs, variabel ini memberikan pengaruh sebesar $0.4 \%$ dan secara negatif mempengaruhi intensi membeli produk fashion tiruan dengan kriteria tidak signifikan. Hal ini berarti tidak terdapat pengaruh yang signifikan dari control beliefs terhadap intensi membeli produk fashion tiruan. Dengan kata lain dalam membeli produk fashion tiruan, 
konsumen tidak dipengaruhi oleh kesempatan yang ada dan sumber yang tersedia tetapi dipengaruhi oleh faktor lain yang belum mampu dipaparkan dalam penelitian ini.

Selanjutnya, variabel power of factor memberikan pengaruh sebesar $0 \%$ dan secara positif memberikan pengaruh terhadap intensi membeli produk fashion tiruan dengan kriteria tidak signifikan. Hal ini berarti power of factor yang dimiliki seseorang terhadap intensi membeli produk fashion tiruan ternyata tidak memberikan pengaruh terhadap intensi seseorang dalam membeli produk fashion tiruan. Dengan kata lain, persepsi individu mengenai sumber dan kesempatan yang ada untuk membeli produk fashion tiruan tidak memberikan pengaruh dalam menampilkan perilaku membeli produk fashion tiruan, artinya intensi seseorang untuk membeli produk fashion tiruan tidak dipengaruhi oleh faktor kesempatan.

Dimensi dari variabel perceived behavioral control yaitu control beliefs dan perceived power dalam penelitian ini tidak memberikan sumbangan pengaruh yang signifikan. Hal ini tidak mendukung penelitian sebelumnya yang dilakukan oleh Collins \& Mullan (2011), bahwa perceived behavioral control menjadi prediktor paling kuat dalam memprediksi intensi seseorang. Hasil dari penelitian ini menjelaskan bahwa kepercayaan seseorang dalam menampilkan suatu perilaku jika memiliki kecenderungan untuk menampilkan suatu perilaku tertentu seperti membeli produk fashion tiruan tidak memberikan pengaruh secara signifikan.

Jenis kelamin memberikan pengaruh sebesar $0.1 \%$ dan secara positif mempengaruhi intensi membeli produk fashion tiruan dengan kriteria tidak signifikan. Hasil dalam penelitian ini tidak mendukung penelitian sebelumnya yang dilakukan oleh Jason \& Karen (2011), bahwa jenis kelamin berpengaruh secara signifikan terhadap intensi membeli produk fashion tiruan. Hal ini berarti jenis kelamin seseorang tidak memberikan pengaruh terhadap intensi membeli produk fashion tiruan.

Teknik pengambilan sampel yang digunakan non-probability accidental karena sulitnya mengetahui data jumlah dan masih terdapat variabel lain diluar penelitian ini yang belum diteliti.

\section{Saran}

1. Berdasarkan hasil analisis regresi, sumbangan efektif dari hasil penelitian faktor-faktor psikologis yang mempengaruhi intensi membeli produk fashion tiruan menunjukkan pengaruh secara keseluruhan sebesar $33.4 \%$ dan selebihnya dipengaruhi oleh variabel lain. Untuk 
penelitian selanjutnya disarankan agar melakukan penelitian untuk menguji faktor lain yang mempengaruhi intensi membeli produk fashion tiruan seperti materialism (Furnham \& Halldor, dalam Boonghee, 2009), Risk Assessment (Augusto et.al, 2007) dan beberapa variabel demografi seperti pendapatan, profesi dan lain sebagainya. Dengan mempertimbangkan variabel tersebut, diharapkan penelitian selanjutnya akan lebih menyempurnakan hasil dalam penelitian ini.

2. Sampel dalam penelitian ini berjumlah 150 orang. Dengan bertambahnya variabel lain yang akan diteliti, maka jumlah item pun akan bertambah. Jumlah sampel harus ditambah dan disesuaikan dengan kebutuhan penelitian. Penyesuaian karakteristik populasi diharapkan akan memberikan data yang lebih representatif.

3. Penelitian ini bertemakan intensi membeli produk fashion tiruan. Secara tema, ranah penelitian ini memiliki cakupan yang luas, maka untuk penelitian selanjutnya diharapkan peneliti mempersempit ranah penelitian agar hasil yang didapat lebih spesifik, misalnya produk fashion bermerek tertentu yang dipalsukan atau jenis produk fashion (seperti jam tangan, sepatu dan lain-lain).

4. Hasil penelitian menunjukkan variabel motivation to comply berpengaruh secara signifikan $(\mathrm{p}<0.05)$ terhadap intensi membeli produk fashion tiruan. Saran praktis yang dapat diambil adalah:

a. Mempelajari atau menggali informasi lebih dalam mengenai produk fashion agar tidak mudah mengikuti orang lain dalam membeli produk fashion tiruan atau ketika ditawarkan penjual, sehingga tidak mengalami kerugian.

b. Tren fashion datang silih berganti seperti tren jersey klub sepak bola, aksesoris gadget (tongsis, capdase, dan lain-lain), sepatu dan sandal (merek Crocs, New Balance, dan lain-lain), dan batu mulia (black onyx, blue sapphire, moonstone, kecubung, dan lain-lain) yang dalam beberapa tahun terakhir di gemari banyak orang. Sebagai konsumen yang smart, penting untuk memperhatikan daya finansial yang dimiliki, dan memperhatikan kebutuhan materi dengan tidak konsumtif secara berlebihan, sehingga mampu bersikap kritis dengan fenomena pemalsuan produk fashion dan lebih baik dengan menerapkan gaya hidup sederhana (qanaah). 


\section{DAFTAR PUSTAKA}

Ahira, Anne. (2013). Mitos dan fakta mengenai fashion. Diunduh tanggal 17 November 2013 dari http://www.anneahira.com.

Ajzen, I. (2012). Attitudes and persuasion. In K, Deaux \& M, Snyder(Ed). The oxford Handbook of Personality and Social Psychology(367-393). New York:Oxford University Press.

Assael, Henry. (1998). Consumer behavior and marketing action. Ohio: SouthWestern College Publishing.

Augusto, C.,Trindade, C.I., \& Alberto, C. (2007). Consumer attitudes toward counterfeits: a review and extension. Journal of Consumer Marketing, 0736-3761.

Carpenter, John M \& Lear, Karen. (2011). Consumer attitudes toward counterfeit fashion product: does gender matter?. Journal of Textile and Apparel, Technology and Management, 7, issue 1.

Collins,A., \& Mullan, B. (2011). An extension of the theory of planned Behavior to predict immediate hedonic behaviours and distal benefits behaviours. Food Quality and Preference, 22(7), 638-646.

Cronan, T.P., \& Al-Rafee, S. (2008). Factors that influence the Intention to Pirate Software and Media. Journal of Business Ethics, 78, 527-545.

Davis, L., Saunders, J., Johnson, S., \& Miller-Cribs, J. (2002). Predicting positive academic intentions among african american males and females. Journal of Applied Social Psychology, 11, 143-150.

Eagly, A.H., \& Chaiken, S. (1993). The psychology of attitudes. Florida: Harcourt Brace Jovanovich.

Engel, James F. , Blackwell, Roger D. \& Miniard, Paul W. (2006). Perilaku konsumen: Jilid 2. Tangerang: Binarupa Aksara Publisher.

Fashion Pro. (2010). Kamus mode. Jakarta : Dian Rakyat

Feldman,R.S. (1995). Social psychology. New Jersey: Prentice Hall.

Geo. (2012). Orang Indonesia gemar membeli barang palsu. Diunduh tanggal 7 November 2013 dari http://www.forum.kompas.com.

Girard, Tulay. (2010). The role of demographics on the susceptibility to social influence: A pretest study. Journal of Marketing Development and Competitiveness. 5, 9-22.

Goodwin, R.E., \& Mullan, B.A. (2009). Predictor of undergraduates intention to incorporate glycaemix index into dietary behavior. Nutritions and Dietetics, 66(1), 54-59.

Hogg, M.A., \& Vaughan, G. M. (2002). Social psychology: Third edition. London: Pearson Education.

Organization for Economic Co-operation and Development. (1998). The economic impact of counterfeiting. Retrieved December 12, 2012, from http://www.oecd.org/sti/industryyandglobalization/2090589.pdf. 
